\title{
The Beneficial Effects of Using Royal Jelly, Arginine and Trytophane on Fruiting of Superior Grapevines
}

\author{
M. A. M. Abada* and Basma R. Ahmed** \\ *Viticulture Department, Horticulture Research Institute, and \\ ** Plant Nutrition Department, Soil, Water and Environ. Res., \\ Agricultural Research Centre, Cairo, Egypt.
}
THIS STUDY was carried out during 2013 and 2014 seasons to test the effect of spraying roy al jelly, arginine or tryptophane each at 0.025 to $0.1 \%$ three times on growth, plant pigments, leaf $\mathrm{N}, \mathrm{P}, \mathrm{K}$ and $\mathrm{Mg}$, yield and fruit quality of Superior grapevines.

Three sprays of royal jelly, arginine, tryptophane each at 0.025 to $0.1 \%$ resulted in an obvious promotion on all growth traits, plant pigments and leaf content of $\mathrm{N}, \mathrm{P}, \mathrm{K}$ and $\mathrm{Mg}$, yield as well as physical and chemical characteristics of the berries relative to the control treatment. The promotion was materially related to the increase in concentrations of the three stimulants. Increasing concentration from each stimulant from 0.05 to $0.1 \%$ had no significant promotion on these characters. The best results were obtained due to using royal jelly, arginine and tryptophane, in descending order.

Carrying out three sprays of royal jelly at $0.05 \%$ to Superior grapevines resulted in the best results with regard to yield and quality of the berries.

Keywords: Royal jelly, Arginine, Tryptophane, Superior grapevine, Yield and Fruit quality

\begin{abstract}
Superior grapevine cv. grown under Minia region conditions faces some problems such as low yield and high shot berries in the clusters. Many trials were conducted for using stimulants such as royal jelly and amino acids as a replacement of chemical fertilizers for solving such problems. Recently, studies carried out here or abroad encourage the application of these stimulants for improving yield and quality of the berries in different grapevine cvs. Rare literatures are available about the impact of royal jelly on horticultural crops. Royal jelly is secreted form the heads of queen bees form pollens, water and honey mixed with saliva, hormones, and vitamins. It contains higher amounts of proteins, lipids, fructose, glucose, sucrose, minerals such $\mathrm{K}, \mathrm{Mg}, \mathrm{Ca}, \mathrm{Fe}, \mathrm{P}, \mathrm{S}$, $\mathrm{Mn}$ and $\mathrm{Si}$ and vitamins such as $\mathrm{B}_{1} \& \mathrm{~B}_{2} \& \mathrm{~B}_{5} \& \mathrm{~B}_{6} \& \mathrm{~B}_{8} \& \mathrm{~B}_{9}, \mathrm{~B}_{12}, \mathrm{~A}, \mathrm{C}, \mathrm{D}$, $\mathrm{K}$ and E. Also, it contains gonadortohic and sex hormones (Huey, 1951 and Nation \& Robinson, 1971).
\end{abstract}


The two essential amino acids namely arginine and tryptophane are very important for protecting all plant cells from free radicals that destroyed plant cell as well as increasing the tolerance of plants to all stresses. They are responsible for enhancing cell division, enzymes, plant pigments and natural hormones like ethylene and IAA (Nijjar, 1985).

Previous studies showed that application of royal jelly was accompanied with stimulating all growth characters, vine nutritional status, yield and fruit quality of horticultural crops (El- Maziny \& Hassan, 1990, El- Shaikh, 2010, Al-Wasfy, 2013 and Gad El-Kareem \& Abada, 2014).

The results of Ahmed \& Abd El-Hameed, (2003), Amin (2007) Ahmed et al. (2007a) \& (2007b), Seleem-Basma \& Abd El-Hameed (2008), El-Hanafy (2010), Ahmed et al. (2011) Wassel et al. (2011), Abdelaal (2012) and Mohamed (2014) emphasized the beneficial effects of spraying amino acids on growth and fruiting of different fruit crops.

The target of this study was examining the effect of spraying royal jelly as well as the two amino acids namely arginine and tryptophane on growth, vine nutritional status, yield as well as physical and chemical characteristics of Superior grapes.

\section{Material and Methods}

This study was carried out during 2013 and 2014 seasons on ninety 6years old Superior grapevines. The selected vines were grown in a private vineyard located at El- Hawarta village, Minia district, Minia Governorate where the soil is silty clay. Vines are spaced at $2 \times 3$ meters apart. At the middle of Jan., the vines were pruned using cane pruning system and gable supporting system was adopted. Vine load for all the selected vines was 84 eyes (in the basis of six fruiting cane * twelve eyes plus six renewal spurs * two eyes). Surface irrigation system was followed. Horticultural practices were carried out as usual.

The study included the following ten treatments:

- Control.

- $\quad$ Spraying royal jelly at $0.025 \%$.

- Spraying royal jelly at $0.05 \%$.

- $\quad$ Spraying royal jelly at $0.1 \%$.

- $\quad$ Spraying arginine at $0.025 \%$.

- $\quad$ Spraying arginine at $0.05 \%$.

- $\quad$ Spraying arginine at $0.1 \%$.

- $\quad$ Spraying tryptophane at $0.025 \%$.

- $\quad$ Spraying tryptophane at $0.05 \%$.

- $\quad$ Spraying tryptophane at $0.1 \%$. 
Each treatment was replicated three times, three vines per each. Royal jelly (Table 1) arginine and tryptophane were sprayed three times at growth start (last week of Feb.), just after berry setting (last week of April) and three weeks later ( $3^{\text {rd }}$ week of May). Triton B as a wetting agent was applied at $0.05 \%$ to all solutions. The selected vines were sprayed with these stimulants till runoff. Randomized complete block design was followed.

At the last week of May, during both seasons, growth characters namely main shoot length, number of leaves/ main shoot and leaf area $\left(\mathrm{cm}^{2}\right)$ (Ahmed and Morsy, 1999) were measured in the ten labeled main shoot/ vine. At the middle of Jan. and after winter pruning, weight of one -year old wood $(\mathrm{kg})$ and cane thickness $(\mathrm{cm})$ were recorded. Plant pigments namely chlorophylls a \& b and total chlorophylls (mg/ $100 \mathrm{~g}$ F.W.) in the leaves (Von-Wettstein, 1957) percentages of $\mathrm{N}, \mathrm{P}, \mathrm{K}$ and $\mathrm{Mg}$ (one dry weight basis) (Wilde et al., 1985 and Balo et al., 1988).

TABLE 1. Chemical analysis of royal jelly (Townsend and Lucas, 1966).

\begin{tabular}{|c|c|}
\hline Constituents & Values $\mathrm{mg} / 100 \mathrm{~g}$ F.W. \\
\hline Water & 65.3 \\
\hline Dry matter & 34.7 \\
\hline Portents & 48.2 \\
\hline Carbohydrate & 37.8 \\
\hline Lipids & 10.4 \\
\hline Ash & 2.0 \\
\hline Sugar & 23.0 \\
\hline Glucose & 4.0 \\
\hline Fructose & 4.0 \\
\hline Sucrose & 5.0 \\
\hline $\mathrm{K}$ & 220 \\
\hline $\mathrm{Mg}$ & 105 \\
\hline $\mathrm{Ca}$ & 112 \\
\hline $\mathrm{Fe}$ & 50 \\
\hline $\mathrm{P}$ & 118 \\
\hline $\mathrm{S}$ & 44 \\
\hline $\mathrm{Mn}$ & 32 \\
\hline $\mathrm{Si}$ & 5 \\
\hline Vitamins $B_{1}$ & 0.4 \\
\hline Vitamins $B_{2}$ & 0.3 \\
\hline Vitamins $B_{5}$ & 0.4 \\
\hline Vitamins $B_{6}$ & 0.3 \\
\hline Vitamins $\mathrm{B}_{8}$ & 0.3 \\
\hline Vitamins $B_{9}$ & 0.4 \\
\hline Vitamins $\mathrm{B}_{12}$ & 0.3 \\
\hline $\mathrm{A}$ & 0.4 \\
\hline $\mathrm{C}$ & 0.9 \\
\hline $\mathrm{D}$ & 0.5 \\
\hline $\mathrm{K}$ & 0.4 \\
\hline $\mathrm{E}$ & 0.3 \\
\hline Essential amino acids & 1100 \\
\hline
\end{tabular}


Harvesting was done when TSS/acid ratio in the untreated berries reached $25 \%$ (last week of June). Yield/ vine expressed in number of clusters/vine and weight (kg.) was recorded. Five clusters/ vine were harvested for determination of cluster weight $(\mathrm{g})$, shot berries $\%$, berry weight $(\mathrm{g})$, TSS $\%$, reducing sugars $\%$ and total acidity \% ( as g tartaric acid/ $100 \mathrm{ml}$ juice) (A.O.A.C., 2000).

Statistical analysis was done using new L.S.D. test for made all comparisons between treatment means (Mead et al., 1993).

Vegetative growth

\section{Results and Discussion}

Data in Table 2 clearly show that spraying royal jelly, arginine, tryptophane each at 0.025 to $0.1 \%$ three times significantly stimulated main shoot length, number of leaves / shoot, leaf area, pruning wood and cane thickness relative to the check treatment. The promotion was significantly associated with increasing concentrations from 0.025 to $0.1 \%$. Increasing concentrations from 0.05 to $0.1 \%$ had no significant effect on these growth characters. Using royal jelly, arginine and tryptophane, in descending order was significantly very effective in enhancing these growth traits. The maximum values were recorded on the vines that received three sprays of royal jelly at $0.1 \%$. Untreated vines produced the minimum values. These results were true during both seasons.

TABLE 2. Effect of spraying royal jelly, arginine and tryptophane on some vegetative growth characters of Superior grape vines during 2013 and 2014 seasons .

\begin{tabular}{|l|c|c|c|c|c|c|c|c|c|c|}
\hline \multirow{2}{*}{ Treatment } & \multicolumn{2}{|c|}{$\begin{array}{c}\text { Main shoot } \\
\text { length (cm) }\end{array}$} & \multicolumn{2}{|c|}{$\begin{array}{c}\text { No. of leaves } \\
\text { per shoot }\end{array}$} & \multicolumn{2}{|c|}{ Leaf area (cm) } & \multicolumn{2}{|c|}{$\begin{array}{c}\text { Pruning } \\
\text { wood/ vine } \\
(\mathbf{k g})\end{array}$} & \multicolumn{2}{|c|}{$\begin{array}{c}\text { Cane } \\
\text { thickness } \\
(\mathbf{c m})\end{array}$} \\
\cline { 2 - 12 } & $\mathbf{2 0 1 3}$ & $\mathbf{2 0 1 4}$ & $\mathbf{2 0 1 3}$ & $\mathbf{2 0 1 4}$ & $\mathbf{2 0 1 3}$ & $\mathbf{2 0 1 4}$ & $\mathbf{2 0 1 3}$ & $\mathbf{2 0 1 4}$ & $\mathbf{2 0 1 3}$ & $\mathbf{2 0 1 4}$ \\
\hline \multicolumn{1}{|c|}{ Control } & 90.0 & 91.3 & 19.0 & 18.7 & 109.3 & 110.0 & 1.41 & 1.43 & 1.09 & 1.07 \\
\hline $\begin{array}{l}\text { Royal jelly at } \\
0.025 \%\end{array}$ & 105.3 & 106.0 & 26.0 & 27.0 & 125.0 & 126.1 & 2.10 & 2.16 & 1.44 & 1.47 \\
\hline $\begin{array}{l}\text { Royal jelly at } \\
0.05 \%\end{array}$ & 108.0 & 108.8 & 28.0 & 29.0 & 127.0 & 128.2 & 2.21 & 2.27 & 1.61 & 1.64 \\
\hline $\begin{array}{l}\text { Royal jelly at } \\
0.1 \%\end{array}$ & 108.3 & 109.1 & 28.7 & 29.3 & 127.3 & 128.5 & 2.22 & 2.28 & 1.62 & 1.65 \\
\hline $\begin{array}{l}\text { Arginine at } \\
0.025 \%\end{array}$ & 98.9 & 99.7 & 23.0 & 24.0 & 118.3 & 119.5 & 1.85 & 1.91 & 1.31 & 1.35 \\
\hline $\begin{array}{l}\text { Arginine at } \\
0.05 \%\end{array}$ & 102.6 & 103.4 & 24.3 & 25.5 & 121.0 & 122.1 & 1.97 & 2.03 & 1.38 & 1.42 \\
\hline $\begin{array}{l}\text { Arginine at } \\
0.1 \%\end{array}$ & 108.0 & 103.7 & 24.7 & 25.7 & 121.3 & 122.4 & 1.98 & 2.04 & 1.39 & 1.43 \\
\hline $\begin{array}{l}\text { Tryptophane at } \\
0.025 \%\end{array}$ & 92.7 & 93.5 & 20.3 & 21.6 & 112.0 & 113.1 & 1.52 & 1.58 & 1.15 & 1.18 \\
\hline $\begin{array}{l}\text { Tryptophane at } \\
0.05 \%\end{array}$ & 95.0 & 95.7 & 21.3 & 22.8 & 115.0 & 116.2 & 1.64 & 1.70 & 1.22 & 1.23 \\
\hline $\begin{array}{l}\text { Tryptophane at } \\
0.1 \%\end{array}$ & 95.3 & 95.8 & 21.6 & 23.0 & 115.3 & 116.4 & 1.65 & 1.71 & 1.23 & 1.24 \\
\hline $\begin{array}{l}\text { New L.S.D. at } \\
5 \%\end{array}$ & 1.4 & 1.5 & 1.1 & 1.1 & 1.3 & 1.3 & 0.09 & 0.08 & 0.04 & 0.04 \\
\hline
\end{tabular}

Egypt. J. Hort. Vol. 42, No.1 (2015) 


\section{Chemical composition}

It is clear from the data in Tables $3 \& 4$ that spraying the three stimulants at 0.025 to $0.1 \%$ significantly enhanced chlorophylls a \& b, total chlorophylls as well as percentages of $\mathrm{N}, \mathrm{P}, \mathrm{K}$ and $\mathrm{Mg}$ in the leaves comparing to the control treatment. The best material in this respect was royal jelly followed by arginine. Tryptophane occupied the last position in this respect. Meaningless promotion on these constituents was observed due to raising concentrations of each material from 0.05 to $0.1 \%$. The maximum values were recorded on the vines that received royal jelly at $0.1 \%$. The lowest values were recorded on the untreated vines. These results were true during both seasons.

TABLE 3. Effect of spraying royal jelly, arginine and tryptophane on some plant pigments and percentages of $N$ and $P$ in the leaves Superior grapevines during 2013 and 2014 seasons .

\begin{tabular}{|l|c|c|c|c|c|c|c|c|c|c|}
\hline \multirow{2}{*}{ Treatment } & $\begin{array}{c}\text { Chlorophylla } \\
\text { (mg/ 1.0 g } \\
\text { F.W.) }\end{array}$ & $\begin{array}{c}\text { Chlorophyllb } \\
\text { (mg/ 1.0 g } \\
\text { F.W.) }\end{array}$ & \multicolumn{2}{|c|}{$\begin{array}{c}\text { Total } \\
\text { chlorophylls } \\
(\mathbf{m g} / 1.0 \text { F.W. }\end{array}$} & \multicolumn{2}{|c|}{ Leaf N \% } & \multicolumn{2}{|c|}{ Leaf P \% } \\
\cline { 2 - 11 } & $\mathbf{2 0 1 3}$ & $\mathbf{2 0 1 4}$ & $\mathbf{2 0 1 3}$ & $\mathbf{2 0 1 4}$ & $\mathbf{2 0 1 3}$ & $\mathbf{2 0 1 4}$ & $\mathbf{2 0 1 3}$ & $\mathbf{2 0 1 4}$ & $\mathbf{2 0 1 3}$ & $\mathbf{2 0 1 4}$ \\
\hline Control & 1.11 & 1.09 & 0.39 & 0.35 & 1.50 & 1.44 & 1.64 & 1.60 & 0.17 & 0.16 \\
\hline $\begin{array}{l}\text { Royal jelly } \\
\text { at 0.025\% }\end{array}$ & 1.75 & 1.81 & 0.73 & 0.73 & 2.48 & 2.54 & 2.05 & 2.11 & 0.36 & 0.36 \\
\hline $\begin{array}{l}\text { Royal jelly } \\
\text { at 0.05\% }\end{array}$ & 1.92 & 1.98 & 0.79 & 0.80 & 2.71 & 2.78 & 2.12 & 2.18 & 0.40 & 0.40 \\
\hline $\begin{array}{l}\text { Royal jelly } \\
\text { at 0.1\% }\end{array}$ & 1.93 & 1.99 & 0.80 & 0.81 & 2.73 & 2.80 & 2.13 & 2.19 & 0.41 & 0.41 \\
\hline $\begin{array}{l}\text { Arginine at } \\
0.025 \%\end{array}$ & 1.44 & 1.50 & 0.59 & 0.57 & 2.03 & 2.07 & 1.88 & 1.95 & 0.29 & 0.29 \\
\hline $\begin{array}{l}\text { Arginine at } \\
0.05 \%\end{array}$ & 1.54 & 1.60 & 0.65 & 0.64 & 2.19 & 2.24 & 1.97 & 2.03 & 0.31 & 0.32 \\
\hline $\begin{array}{l}\text { Arginine at } \\
0.1 \%\end{array}$ & 1.55 & 1.61 & 0.66 & 0.65 & 2.26 & 2.26 & 1.98 & 2.04 & 0.32 & 0.33 \\
\hline $\begin{array}{l}\text { Tryptophane } \\
\text { at 0.025\% }\end{array}$ & 1.21 & 1.28 & 0.45 & 0.42 & 1.66 & 1.70 & 1.71 & 1.78 & 0.20 & 0.21 \\
\hline $\begin{array}{l}\text { Tryptophane } \\
\text { at 0.05\% }\end{array}$ & 1.31 & 1.38 & 0.50 & 0.48 & 1.81 & 1.86 & 1.79 & 1.86 & 0.24 & 0.24 \\
\hline $\begin{array}{l}\text { Tryptophane } \\
\text { at 0.1\% }\end{array}$ & 1.32 & 1.39 & 0.51 & 0.49 & 1.83 & 1.88 & 1.80 & 1.87 & 0.24 & 0.24 \\
\hline $\begin{array}{l}\text { NewL.S.D. } \\
\text { at 5\% }\end{array}$ & 0.08 & 0.08 & 0.05 & 0.06 & 0.08 & 0.07 & 0.05 & 0.06 & 0.02 & 0.03 \\
\hline
\end{tabular}

Yield and cluster weight and number

Data in Table 4 obviously reveal that treating the vines three times with royal jelly, arginine and tryptophane each at 0.025 to $0.1 \%$ significantly was responsible for improving the yield expressed in number of clusters/vine and yield per vine and cluster weight relative to the check treatment. There was a gradual promotion on the yield and cluster weight with increasing concentrations of each material. 
Significant differences on these parameters were observed among all concentrations except between the higher two concentrations namely 0.05 and $0.1 \%$ from each material. Therefore, from economical point of view the best treatment in this respect was the application of royal jelly three times at $0.05 \%$. Under such promised treatment, yield reached 11.5 and $13.5 \mathrm{~kg}$ during both seasons, respectively. The control vines produced 8.3 and $8.7 \mathrm{~kg}$ during 2013 and 2014 seasons, respectively. The percentage of increase on the yield due to application of the promised treatment over the check treatment reached 38.6 and $55.2 \%$ during both seasons, respectively. These results were true during both seasons.

TABLE 4. Effect of spraying royal jelly, arginine and tryptophane on percentages of $\mathrm{K}$ and $\mathrm{Mg}$, yield and average cluster weight of Superior grapevines during 2013 and 2014 seasons .

\begin{tabular}{|l|c|c|c|c|c|c|c|c|c|c|}
\hline \multirow{2}{*}{ Treatment } & \multicolumn{2}{|c|}{ Leaf K \% } & \multicolumn{3}{|c|}{ Leaf Mg \% } & \multicolumn{2}{c|}{$\begin{array}{c}\text { No. of clusters/ } \\
\text { vine }\end{array}$} & \multicolumn{2}{|c|}{$\begin{array}{c}\text { Yield/ vine } \\
\text { (kg) }\end{array}$} & \multicolumn{2}{|c|}{$\begin{array}{c}\text { Average } \\
\text { cluster weight } \\
\text { (g) }\end{array}$} \\
\cline { 2 - 12 } & $\mathbf{2 0 1 3}$ & $\mathbf{2 0 1 4}$ & $\mathbf{2 0 1 3}$ & $\mathbf{2 0 1 4}$ & $\mathbf{2 0 1 3}$ & $\mathbf{2 0 1 4}$ & $\mathbf{2 0 1 3}$ & $\mathbf{2 0 1 4}$ & $\mathbf{2 0 1 3}$ & $\mathbf{2 0 1 4}$ \\
\hline Control & 1.29 & 1.31 & 0.39 & 0.35 & 22.0 & 23.0 & 8.3 & 8.7 & 376.0 & 380.0 \\
\hline $\begin{array}{l}\text { Royal jelly at } \\
0.025 \%\end{array}$ & 1.71 & 1.75 & 0.72 & 0.69 & 23.0 & 28.0 & 10.8 & 13.3 & 471.0 & 475.0 \\
\hline $\begin{array}{l}\text { Royal jelly at } \\
0.05 \%\end{array}$ & 1.80 & 1.85 & 0.80 & 0.77 & 24.0 & 28.0 & 11.5 & 13.5 & 480.0 & 481.0 \\
\hline $\begin{array}{l}\text { Royal jelly at } \\
0.1 \%\end{array}$ & 1.80 & 1.86 & 0.81 & 0.78 & 24.0 & 28.0 & 11.5 & 13.5 & 481.0 & 482.0 \\
\hline $\begin{array}{l}\text { Arginine at } \\
0.025 \%\end{array}$ & 1.50 & 1.55 & 0.57 & 0.55 & 23.0 & 26.0 & 9.7 & 11.1 & 421.0 & 426.0 \\
\hline $\begin{array}{l}\text { Arginine at } \\
0.05 \%\end{array}$ & 1.60 & 1.64 & 0.64 & 0.61 & 23.0 & 27.0 & 10.4 & 12.3 & 450.0 & 456.0 \\
\hline $\begin{array}{l}\text { Arginine at } \\
0.1 \%\end{array}$ & 1.61 & 1.65 & 0.65 & 0.62 & 23.0 & 27.0 & 10.4 & 12.3 & 451.0 & 457.0 \\
\hline $\begin{array}{l}\text { Tryptophane } \\
\text { at 0.025\% }\end{array}$ & 1.36 & 1.40 & 0.44 & 0.40 & 23.0 & 24.0 & 8.8 & 9.3 & 383.0 & 387.0 \\
\hline $\begin{array}{l}\text { Tryptophane } \\
\text { at 0.05\% }\end{array}$ & 1.42 & 1.47 & 0.50 & 0.47 & 23.0 & 25.0 & 9.2 & 10.1 & 401.0 & 405.0 \\
\hline $\begin{array}{l}\text { Tryptophane } \\
\text { at 0.1\% }\end{array}$ & 1.43 & 1.48 & 0.51 & 0.48 & 23.0 & 25.0 & 9.2 & 10.2 & 402.0 & 406.0 \\
\hline $\begin{array}{l}\text { New L.S.D. } \\
\text { at 5\% }\end{array}$ & 0.05 & 0.04 & 0.04 & 0.05 & NS & 1.0 & 0.3 & 0.2 & 15.1 & 14.9 \\
\hline
\end{tabular}

\section{Shot berries}

Table 5 shows that the percentage of shotberries was significantly reduced with using the three stimulants each at 0.025 to $0.1 \%$ relative to the check treatment. The reduction on shotberries was significantly relative to the increase in the percentage of royal jelly, arginine and tryptophane concentrations from 0.025 to $0.1 \%$. No significant reduction was observe due to increasing concentrations from each material from 0.05 to $0.1 \%$. The best material in checking shotberries in the clusters of Superior grapevines was royal jelly followed by arginine. The lowest values of shot berries (3.0 and $2.8 \%$ ) were recorded on the vines that received three sprays of royal jelly at $0.1 \%$. The highest values $(8.0 \& 8.1 \%)$ were recorded on untreated vines. The same trend was noticed during both seasons.

Egypt. J. Hort. Vol. 42, No.1 (2015) 
Berry quality

It is obvious from the obtained data in Table 5 that treating the vines with royal jelly, arginine and tryptophane each at 0.025 to $0.1 \%$ significantly was very effective in improving fruit quality in terms of increasing berry weight, TSS \% and reducing sugars $\%$ and decreasing total acidity $\%$ relative to the control treatment. The promotion was significantly associated with increasing concentrations of each material. Using royal jelly was significantly superior than using the other two amino acids in enhancing quality of the berries. The best results with regard to fruit quality were obtained due to treating the vin es three times with royal jelly at $0.1 \%$ but from economical point of view it is suggested to use royal jelly at $0.05 \%$. Unfavourable effects on fruit quality were observed on untreated vines. The same trend was noticed during both seasons.

TABLE 5. Effect of spraying royal jelly, arginine and tryptophane on percentage of shot berries as well as some physical and chemical characteristics of the grapes of Superior grapevines during 2013 and 2014 seasons.

\begin{tabular}{|l|c|c|c|c|c|c|c|c|c|c|}
\hline \multirow{2}{*}{ Treatment } & \multicolumn{2}{|c|}{ Shot berries \% } & \multicolumn{2}{|c|}{$\begin{array}{c}\text { Average berry } \\
\text { weight (g) }\end{array}$} & \multicolumn{2}{c|}{ T.S.S. \% } & \multicolumn{2}{c|}{$\begin{array}{l}\text { Reducing } \\
\text { sugars \% }\end{array}$} & \multicolumn{2}{c|}{ Total acidity \% } \\
\cline { 2 - 11 } & $\mathbf{2 0 1 3}$ & $\mathbf{2 0 1 4}$ & $\mathbf{2 0 1 3}$ & $\mathbf{2 0 1 4}$ & $\mathbf{2 0 1 3}$ & $\mathbf{2 0 1 4}$ & $\mathbf{2 0 1 3}$ & $\mathbf{2 0 1 4}$ & $\mathbf{2 0 1 3}$ & $\mathbf{2 0 1 4}$ \\
\hline \multicolumn{1}{|c|}{ Control } & 8.0 & 8.1 & 4.00 & 4.00 & 18.0 & 17.9 & 15.7 & 15.5 & 0.720 & 0.717 \\
\hline $\begin{array}{l}\text { Royal jelly at } \\
0.025 \%\end{array}$ & 3.7 & 3.5 & 4.80 & 4.91 & 19.8 & 20.0 & 17.4 & 17.5 & 0.582 & 0.580 \\
\hline $\begin{array}{l}\text { Royal jelly at } \\
0.05 \%\end{array}$ & 3.0 & 2.8 & 4.95 & 5.06 & 20.1 & 20.3 & 17.7 & 17.8 & 0.550 & 0.548 \\
\hline $\begin{array}{l}\text { Royal jelly at } \\
0.1 \%\end{array}$ & 2.9 & 2.7 & 4.97 & 5.07 & 20.2 & 20.4 & 17.8 & 17.9 & 0.549 & 0.548 \\
\hline $\begin{array}{l}\text { Arginine at } \\
0.025 \%\end{array}$ & 6.0 & 5.8 & 4.50 & 4.61 & 19.0 & 19.2 & 16.6 & 16.7 & 0.641 & 0.639 \\
\hline $\begin{array}{l}\text { Arginine at } \\
0.05 \%\end{array}$ & 5.4 & 5.2 & 4.62 & 4.73 & 19.3 & 19.5 & 16.9 & 17.0 & 0.620 & 0.618 \\
\hline $\begin{array}{l}\text { Arginine at } \\
0.1 \%\end{array}$ & 5.3 & 5.1 & 4.63 & 4.74 & 19.4 & 19.6 & 17.0 & 17.1 & 0.618 & 0.617 \\
\hline $\begin{array}{l}\text { Tryptophane } \\
\text { at 0.025\% }\end{array}$ & 7.4 & 7.2 & 4.11 & 4.22 & 18.2 & 18.5 & 15.9 & 16.0 & 0.694 & 0.692 \\
\hline $\begin{array}{l}\text { Tryptophane } \\
\text { at 0.05\% }\end{array}$ & 6.9 & 6.7 & 4.25 & 4.37 & 18.5 & 18.8 & 16.2 & 16.3 & 0.670 & 0.668 \\
\hline $\begin{array}{l}\text { Tryptophane } \\
\text { at 0.1\% }\end{array}$ & 6.8 & 6.6 & 4.26 & 4.38 & 18.6 & 18.9 & 16.3 & 16.4 & 0.669 & 0.667 \\
\hline $\begin{array}{l}\text { New L.S.D. } \\
\text { at 5 \% }\end{array}$ & 0.4 & 0.4 & 0.09 & 0.10 & 0.2 & 0.2 & 0.2 & 0.2 & 0.019 & 0.018 \\
\hline
\end{tabular}

Discussion

The higher content of royal jelly from amino acids, protein fats, sugars, vitamins, mineral and other antioxidants are responsible for its positive action on growth and fruiting of Superior grapevines (Townsend and Lucas, 1966).

These results are in harmony with those obtained by El- Maziny \& Hassan (1990), El-Sheikh (2010), Al-Wasfy (2013) and Gad El-Kareem \& Abada (2014). 
The beneficial effects of amino acids on enhancing cell division, the biosynthesis of plant pigments and natural hormones (Nijjar, 1985) surely reflected on improving fruiting of Superior grapevines.

These results are in agreement with those obtained by El- Hanafy (2010), Ahmed et al. (2011), Abdelaal (2012) and Mohamed (2014).

\section{Conclusion}

Three sprays of royal jelly at $0.05 \%$ at growth start, just after berry setting and three weeks later was responsible for promoting yield and fruit quality of Superior grapevines grown under Minia region.

\section{References}

Abdelaal, E.E.H.A. (2012) The synergistic effects of using some nutrients as well as antioxidant substances on growth, nutritional status and productivity of Thompson seedless grapevines grown under Sohag region. Ph.D. Thesis, Fac. Agric., Sohag Univ., Egypt.

Ahmed, A.H. and Abd El-Hameed, H.M. (2003) Growth, uptake of some nutrients and productivity of Red Roomy vines as affected by spraying of some amino acids, magnesium and boron. Minia J. Agric. Res. Develop., 23(4), 649-666.

Ahmed, F.F. and Morsy, M.H. (1999) A new method for measuring leaf area in different fruit species. Minia. J. Agric. Res. Dev., 19, 97-105.

Ahmed, F.F., Mohamed, M.A., Abd El-aal, A.M.K. and Amin, M.M. (2007a) Response of red Roomy grapevine to application of amino acids and some micronutrients. $3^{\text {rd }}$ Conf. of Sustain Agric. and Develop, Fac. Agric., Fayoum Univ., 12-14 Nov. pp.150- 170.

Ahmed, F.F., Mohamed, M.A., Abd El-aal, A.M.K. and Amin, M.M. (2007b) Response of Red Roomy grapevines to application of amino acid and some micronutrients. $3^{\text {rd }}$ Conf. of sustain Agric. and develop., Fac. Agric., Fayoum Univ., 12-14 Nov. pp. 247-258.

Ahmed, F.F., Asmaa A. Ibrahiem, Mansour, A.E., Shaaban, E.A. and El-Shamaa, M.S. (2011) Response of Thompson seedless grapevines to application of some amino acids enriched with nutrients as well as organic and biofertilization. Res. J. of Agric. and Biological Sci., 7 (2), 282-286.

Al-Wasfy, M.M. (2013) Response of Sakkoti date palms to foliar application of royal jelly, silicon and vitamins B. J. Amer. Sci., 9 (5), 315-321.

Amin, M.M.A. (2007) Response of Red Roomy grapevines to application of amino acid and some micronutrients. M. Sc. Thesis, Fac. Agric., Minia Univ., Egypt.

A.O.A.C. (2000) "Official Methods of Analysis" $16^{\text {th }}$ ed. A.O.A.C., Benjamin Franklin Station, Washington, D.C., .S.A. pp. 490-510.

Egypt. J. Hort. Vol. 42, No.1 (2015) 
Balo, E., Prilesszky, G., Happ, I., Kaholami, M. and Vega, L. (1988) Soil improvement and the use of leaf analysis for forecasting nutrient requirements of grapes. Potash Review, Subject 9, $2^{\text {nd }}$ suite, No. 61, 1-5.

El-Hanafy, W.M.F. (2011) The role of some antioxidants on improving productivity in Red Roomy grapevines viney ard M.Sc. Thesis, Fac. Agric., Minia Univ., Egypt.

El- Maziny, M.Y. and Hassan, M.N.M. (1990) Effect of roy al jelly, vitamin B complex and ethrel on the productivity of cucumber. Minia J. Agric. Res. Des. Dev., 12 (3), 1901-1909.

El-S haikh, Kh. A.A. (2010) Growth and yield of some cucumber cultivars as affected by plant density and royal jelly application. J. Hort. Sci. \& Ornamental Plants 2 (2),131- 137.

Gad El Kareem, M.R. and Abada, M.A.M. (2014) Trials for promoting productivity of Flame seedless grapevines. J. Biol. Chem. Environ. Sci., 9 (1), 35-46.

Hueyl, H.L. (1951) An observation suggesting the presence of gonadotrofic hormone in royal jelly. Sci., 89, 590-591.

Mead, R., Currnow, R.N. and Harted, A.M. (1993) "Statistical Methods in Agricultural and Experimental Biology", $2^{\text {nd }} e d$. , Chapman \& Hall London, pp. 10 - 44.

Mohamed, W.B.F. (2014) Effect of some amino acid, nutrient and salicylic acid treatments on Superior grapevines M.Sc. Thesis, Fac. Agric., Azhar Univ., Egy pt.

Nation, J.L. and Robinson, F.A. (1991) Concentration of some major and trace elements in honey bee, royal jelly and pollen, J. Apic. Res., 10 (1), 35-43.

Nijjar, G.S. (1985) Nutrition of Fruit Trees. Mrs Usah Raj. Kumar, for Kalyani Publishers, New Delhi India, pp. 283 - 302.

Seleem- Basma, M. and Abd El-Hameed, H.M. (2008) Effect of stimulant aminoquelent-Ca on yield and berries quality of Thompson seedless grapevines. Minia J. Agric. Res. \& Develop., 28 (1), 13-21.

Townsend, G. and Lucas, C. (1966) The chemical natural of roy al jelly. Biochemical J., 34, 1115-1162

Von- Wettstein, D.V.C. (1957) Clatale und der Sumbmikro Skopisne Formwechsel de Plastids. Experimental Cell Res., 12- 427.

Wassel, A.M.M., Ahmed, F.F., El-Mamlouk, E.A.H. and Fekry, W.E. (2011) Reliefing cluster loosemners and shot berries in red Roomy grapevines by using some antioxidants, Minia J. of Agric. Res. \& Develop., 31 (2) 205-217.

Wilde, S.A., Corey, R.B., Layer, J.G. and Voigt, G.K. (1985) "Soils and Plant Analysis for Tree Culture", Oxford and IBH publishing Co., New Delhi, India.

(Received 28/9/2014; accepted 29/1/2015) 


$$
\begin{aligned}
& \text { التأثيرات المفيدة لاستخدام الغذاء الملكى، الأرجينين والتربتوفان } \\
& \text { على الإثمار فى كرمات الغب السوبيريور }
\end{aligned}
$$

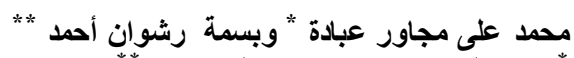

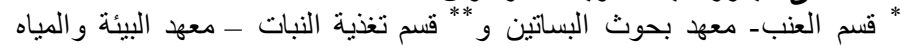

$$
\begin{aligned}
& \text { و التربة - مركز البحوث الزر اعية ـ- القاهرة -مصر. }
\end{aligned}
$$

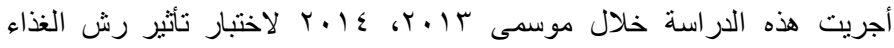

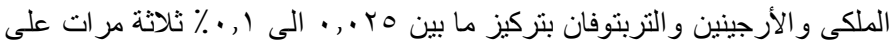

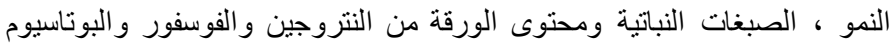
و الماغنسيوم، كمية المحصول وخصائص الجورة الجودة لحبات العنب السوبيريور.

أدى رش الكرمات ثلاثة مر ات بالغذاء الملكى و الأرجينين و التربتوفان بتركيز

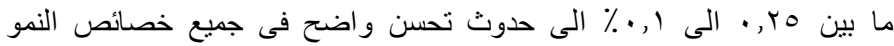

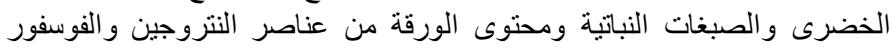

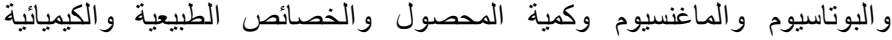

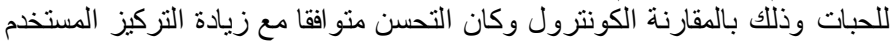

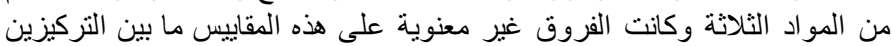

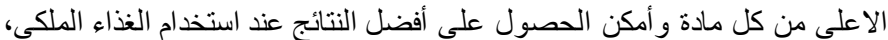
الأرجينينن و التربنوفان مرتبة ترنييا تتازليا.

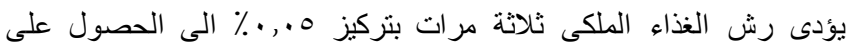
أفضل النتائج بخصوص الفخصول وخصائص الجودة لحبات العنب السوبيريور. 